\title{
Prevalence of six types of human papillomavirus in inverted papilloma and papillary transitional cell carcinoma of the bladder: an evaluation by polymerase chain reaction
}

\author{
K W Chan, K Y Wong, G Srivastava
}

\begin{abstract}
Aims-To study the prevalence of high risk oncogenic human papillomaviruses (HPV) in inverted papilloma and papillary transitional cell carcinoma of the bladder.

Methods-Ten cases of inverted papilloma and 20 cases of papillary transitional cell carcinoma of the bladder from Chinese patients in Hong Kong were examined for the presence of HPV type 6, 11, 16, 18, 31, and 33 genomes using the polymerase chain reaction and HPV type specific primer probe combinations on paraffin wax embedded biopsy specimens.

Results-Of the 10 cases of inverted papilloma, cases 1 and 6 showed the presence of HPV types 16 and 18, respectively. Six of the 20 papillary transitional cell carcinomas were positive for HPV type 18. The other HPV types were not detected.

Conclusions-HPV type 18 was found in $60 \%$ and $30 \%$ of cases of inverted papilloma and papillary transitional cell carcinoma of the bladder, respectively. These tumours were rarely associated with HPV types $6,11,16,31$, and 33 . The role of HPV type 18 in oncogenesis of inverted papilloma and transitional cell carcinoma of the bladder requires further studies. (F Clin Pathol 1997;50:1018-1021)
\end{abstract}

Keywords: inverted papilloma; transitional cell carcinoma; human papillomavirus

Inverted papilloma of the urinary tract is an uncommon benign tumour of the transitional cell epithelium usually found in the urinary bladder. It is characterised by an invaginating growth of transitional cell epithelium that shows no cytological atypia. Little is known about the aetiology of inverted papilloma. The occasional coexistence of inverted papilloma and transitional cell carcinoma suggests a pathogenetic relation. ${ }^{12}$ Early work firmly established the role of chemical carcinogens in the pathogenesis of transitional cell carcinoma of the bladder. Recently, an association between oncogenic human papillomaviruses (HPV) and transitional cell carcinoma of the bladder has been reported repeatedly. ${ }^{3-10}$ However, the prevalence of oncogenic HPV in transitional cell carcinoma was unknown in Hong Kong and the status of oncogenic HPV in inverted papilloma was never studied. Therefore, using the polymerase chain reaction (PCR), we set out to test cases of papillary transitional cell carcinoma and inverted papilloma for the types of HPV that are most commonly studied in association with human genitourinary tumours. The PCR method was selected because of its sensitivity and specificity and its suitability for use on small, paraffin wax embedded biopsy specimens.

\section{Methods}

The biopsy and surgical files of the department of pathology, University of Hong Kong at the Queen Mary Hospital in the years 1987-94 were searched for cases of inverted papilloma of the bladder; 14 patients were identified. These cases were the subject of a previous immunohistological study on p53 overexpression in inverted papilloma of the bladder. ${ }^{11}$ Twenty cases of papillary transitional cell carcinoma of grades I and II obtained through endoscopic biopsy and without evidence of invasion of the bladder wall were selected randomly from the same files. The clinical history as recorded on the pathology request form was noted. The slides were reviewed and the original diagnoses confirmed.

DNA was extracted from routinely processed, formalin fixed, paraffin wax embedded tumour tissues. ${ }^{12}$ Four cases of inverted papilloma of the bladder were excluded owing to insufficient tissue remaining. The quality of DNA extracted was verified by amplifying the $\beta$ globin gene. ${ }^{13}$ Detection of HPV DNA was performed by PCR using type specific DNA primer probe combinations for HPV types $6,{ }^{14}$ $11,{ }^{15} 16,{ }^{16} 18,{ }^{15} 31,{ }^{14}$ and $33 .{ }^{14}$ The oligonucleotide primers used in the PCR for HPV type 16 were complementary to the upstream regulatory region of the viral DNA, while for HPV type 18 they were complementary to sequences in the E6 region. The hybridisation and washing conditions were identical to those reported previously by our laboratory. ${ }^{12}$ Positive controls were performed. Cell lines, used as controls to determine the specificity of the PCR procedures, were obtained from American Type Culture Collection, Maryland, USA. They included: (a) CaSki (400-500 copies of HPV type 16 per cell), (b) SiHa (1-2 copies of HPV type 16 per cell), and (c) HeLa (10-50 copies of HPV type 18 per cell). To determine the sensitivity of the PCR procedures in detecting 

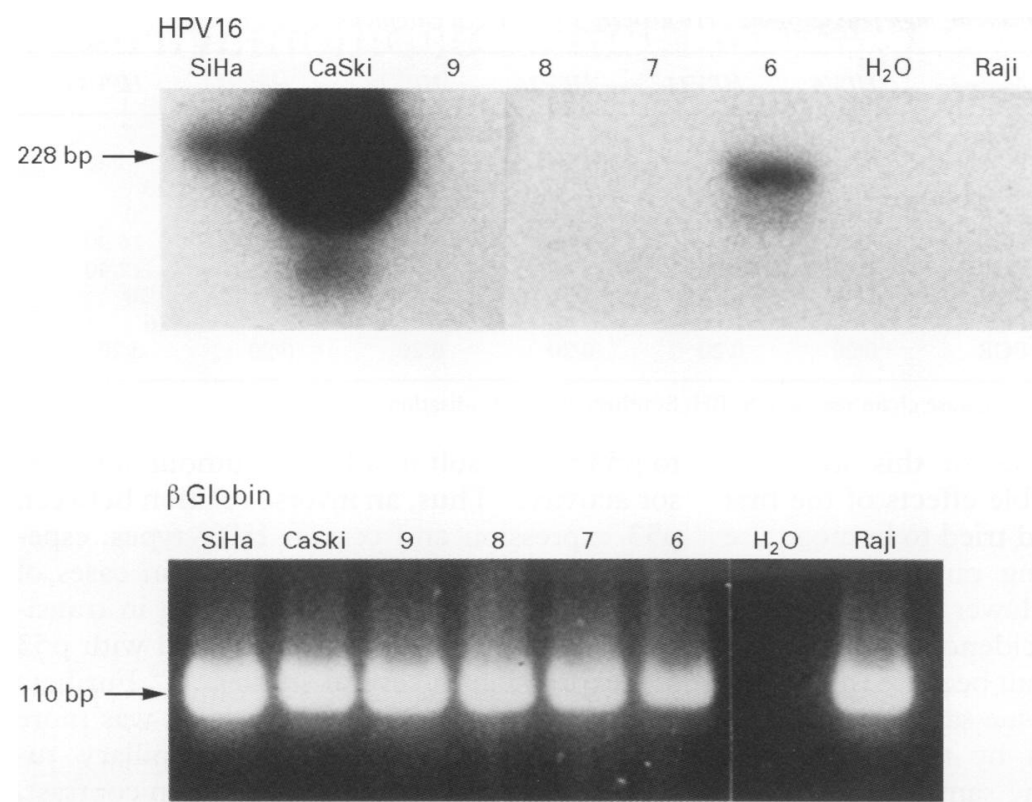

Figure 1 (A) Amplification of HPV type 16 DNA in inverted papilloma case 6 and a negative result for cases 7-9. Other inverted papilloma samples show no amplification. Raji DNA (from an Epstein-Barr virus infected cell line) and distilled water served as negative controls. SiHa and CaSki are HPV type 16 infected cell lines used as positive controls. (B) Amplification of the $\beta$ globin gene in samples of DNA used in the above study. Aliquots of $25 \mathrm{ng}$ of DNA from the control cell lines and $500 \mathrm{ng}$ of DNA from each sample was used for the PCR analysis.

\section{Inverted transitional papilloma}

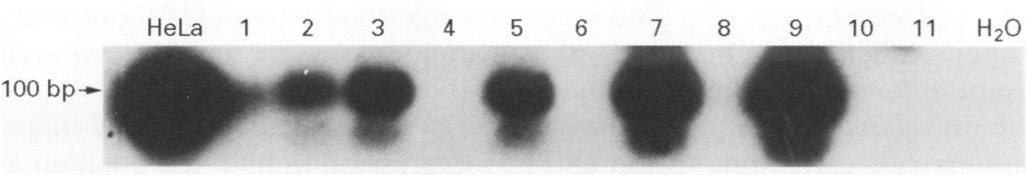

Transitional cell carcinoma
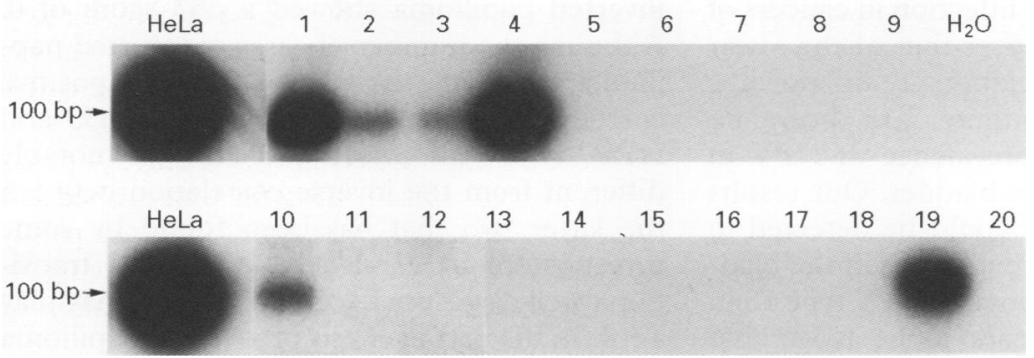

Figure 2 (A) PCR amplification of HPV type 18 DNA is demonstrated in inverted papilloma cases 1,2, 3, 5, 7, and 9. HeL a cells and distilled water are the positive and negative controls. Lanes 10 and 11 are samples from two paraffin blocks of the same case. (B) Six of the 20 cases of transitional cell carcinoma (numbered 1,2, 3, 4, 10, and 19) show the presence of HPV type 18 DNA. Aliquots of $25 \mathrm{ng}$ of DNA from the HeLa cell line and $500 \mathrm{ng}$ of DNA from each sample were used for the PCR analysis.

Table 1 Demographic data and tumour sizes of 10 cases of inverted papilloma of the bladder

\begin{tabular}{lllllll}
\hline Case & Age (years) & Sex & HPV16 & HPV18 & $p 53$ score $^{n t}$ & $\begin{array}{l}\text { Tumour size } \\
(\text { mm) }\end{array}$ \\
\hline 1 & 39 & M & - & + & $3+$ & 12 \\
2 & 52 & M & - & + & $3+$ & 6 \\
3 & 75 & M & - & + & $3+$ & 4 \\
4 & 56 & M & - & - & $1+$ & 12 \\
5 & 56 & F & - & + & $2+$ & 4 \\
6 & 75 & M & + & - & 0 & 10 \\
7 & 43 & F & - & + & $2+$ & 10 \\
8 & 42 & M & - & - & $2+$ & 5 \\
9 & 77 & F & - & + & 0 & 4 \\
10 & 68 & M & - & - & 0 & 10 \\
\hline
\end{tabular}

HPV types 16 and 18 DNA, varying amounts of DNA $(0.1 \mathrm{pg}$ to $1 \mu \mathrm{g})$ from the control cell lines were amplified and hybridised. Distilled water was used as a negative control in each set of PCR reactions. Control primers for $\beta$ globin were amplified successfully in these PCR reactions, verifying that there were no inhibitory elements present in the extracted DNA.

The HPV status in each inverted papilloma was correlated with its p53 score obtained previously. ${ }^{11}$ The methodology for p53 scoring has been described before. Briefly, scoring of p53 was performed on high power fields $(\times 400)$ using a standard light microscope. The percentage of p53 positive cases was determined by counting 500 cells and the cases were separated into four categories: 0 , when fewer than $10 \%$ of the tumour cells were positive; $1+$, when $10 \%$ to fewer than $30 \%$ tumour cells were positive; $2+$, when $30-50 \%$ of the tumour cells were positive; and $3+$, when more than $50 \%$ of the tumour cells were positive.

Statistical analysis was performed using the Fisher's exact test and $\chi^{2}$ test as appropriate.

\section{Results}

HPV type 18 was the only one shown to infect papillary transitional cell carcinoma and was present in six of the 20 cases. Of the 10 cases of inverted papilloma, HPV types 16 and 18 were detected in cases 1 (fig 1 ) and 6 (fig 2), respectively. The demographic data, status of HPV infection, p53 score, ${ }^{11}$ and tumour size of the 10 cases of inverted papilloma of the bladder are shown in table $1 .{ }^{1}$ No significant difference in the prevalence of HPV type 18 positivity could be demonstrated between inverted papilloma and papillary transitional cell carcinoma of the bladder ( $p>0.1$, Fisher's exact test).

PCR analysis for the detection of HPV types 16 and 18 specific DNA sequences on DNA extracted from the $\mathrm{CaSki}$ and $\mathrm{SiHa}$ cell lines (for HPV type 16) and the HeLa cell line (for HPV type 18) yielded a detectable hybridisation signal using a minimum of $25 \mathrm{ng}$ of DNA from the control cell lines. These results were considered adequate for the analysis of the tumour samples.

\section{Discussion}

HPV type 18 was the prevalent oncogenic HPV found in patients with a transitional cell neoplasm of the urinary bladder. High risk oncogenic types of HPV have been frequently reported to be associated with transitional cell carcinoma of the bladder. ${ }^{3-10}$ The molecular techniques used in HPV detection included Southern blot hybridisation, PCR, and in situ hybridisation. Table 2 summarises the results of studies conducted in several centres, including ours. The prevalence of oncogenic HPV in transitional cell carcinoma of the bladder among different studies was highly variable and it was difficult to identify the reasons for this wide variation. The variations could be due to: (a) different types and stages of transitional cell carcinoma, (b) geographical differences in the incidence of HPV infection, and (c) the different sensitivities of the various methods of detection used. When we selected cases of 
Table 2 Summary of the prevalence of high risk oncogenic HPV in transitional cell carcinoma of the bladder

\begin{tabular}{|c|c|c|c|c|c|c|c|}
\hline Reference & Method & HPV6 & $H P V 11$ & HPV16 & HPV18 & HPV31 & $H P V 33$ \\
\hline$\overline{\text { Bryant } e t a l^{\beta}}$ & ISH & \multicolumn{2}{|c|}{$0 / 76$} & \multicolumn{2}{|c|}{$12 / 76$} & 10 & 10 \\
\hline Anwar $e t a l^{4}$ & PCR & \multirow{2}{*}{\multicolumn{2}{|c|}{$22 / 48$}} & $13 / 48$ & $18 / 48$ & \multirow{2}{*}{\multicolumn{2}{|c|}{$1 / 20^{14 / 48}$}} \\
\hline Shibutani et al & SoBH & $2 / 20$ & & \multicolumn{2}{|c|}{$1 / 20$} & & \\
\hline Yu et al & PCR & 10 & 10 & $28 / 53$ & $2 / 53$ & 10 & 10 \\
\hline Furihata et al & ISH & 10 & 10 & $19 / 90$ & $17 / 90$ & 10 & $16 / 90$ \\
\hline Kamel et $a l^{\beta}$ & ISH & $12 / 40$ & $10 / 40$ & $8 / 40$ & $16 / 40$ & $16 / 40$ & $12 / 40$ \\
\hline Lopes Beltran and $\mathrm{Munoz}^{9}$ & PCR & $1 / 76$ & $0 / 76$ & $7 / 76$ & $0 / 76$ & 10 & 10 \\
\hline Tenti et al ${ }^{10}$ & PCR & \multicolumn{2}{|c|}{$0 / 79$} & \multicolumn{2}{|c|}{$12 / 76$} & \multicolumn{2}{|c|}{$0 / 76^{10}$} \\
\hline Present study & PCR & $0 / 20$ & $0 / 20$ & $0 / 20$ & $6 / 20$ & $0 / 20$ & $0 / 20$ \\
\hline
\end{tabular}

ISH, in situ hybridisation; PCR, polymerase chain reaction; SoBH, Southern blot hybridisation.

transitional cell carcinoma for this study we had considered the possible effects of the first variable on the results and tried to homogenise the selection by choosing only non-invasive papillary carcinomas of lower grades. A geographical difference of incidence of HPV infection is difficult to document because this would require the analysis of tissue samples collected from different countries by the same techniques and, ideally, by the same laboratory. It would be of interest to take note of the prevalence of HPV infection in cervical carcinomas in our population. A report from this hospital showed that HPV types 16 and 18, respectively, could be detected in $62 \%$ and $39 \%$ of 64 cases of squamous cell carcinoma of the cervix. ${ }^{17}$ The prevalence of HPV type 16 in cervical squamous cell carcinoma is significantly higher than that of both inverted papilloma and transitional cell carcinoma of the bladder ( $p<0.01$, Fisher's exact test). On the other hand, no significant difference can be demonstrated between the prevalence of HPV type 18 in cervical squamous cell carcinoma and transitional cell carcinoma of the bladder or between that in cervical squamous cell carcinoma and inverted papilloma of the blad$\operatorname{der}\left(p>0.05, \chi^{2}\right.$ test). The reasons for the predilection of HPV type 16 infection in cancers of the female genital tract over that of the lower urinary tract in our population are unknown.

To our knowledge, there has been no previous study on the prevalence of HPV in inverted papilloma of the bladder. Our results show that HPV type 18 could be detected in $60 \%$ of cases of inverted papilloma of the bladder. Although the prevalence of HPV type 18 in inverted papilloma appears to be twice that seen in papillary transitional cell carcinoma, the difference fails to reach statistical significance. Studies on many more cases would be required to clarify whether HPV type 18 is more frequent in inverted papilloma than in papillary transitional cell carcinoma of the bladder.

Our results show that HPV types $6,11,16$, 31 , and 33 are rarely associated with transitional cell tumours of the bladder and that they play little or no role in the pathogenesis of these tumours in Hong Kong.

The p53 gene encodes a $53 \mathrm{kDa}$ nuclear phosphoprotein that is a suppressor of cell growth. ${ }^{18}{ }^{19}$ It is associated with control of the cell cycle, DNA repair and synthesis, cell differentiation, genomic plasticity, and apoptosis. Mutation of the p53 suppressor gene is the most common genetic alteration in human cancer. ${ }^{18}$ Binding of HPV E6 and E7 proteins to p53 may result in a loss of tumour suppressor activity. ${ }^{20}$ Thus, an inverse relation between p53 expression and certain HPV types, especially types 16 and 18 , was found in cases of cervical carcinoma. ${ }^{21} \mathrm{HPV}$ infection in transitional cell carcinoma was correlated with p53 overexpression in several studies. ${ }^{7810}$ Furihata et $a l^{l}$ found that $\mathrm{p} 53$ overexpression was more common in invasive and non-papillary tumours than in high grade tumours. In contrast, HPV infection was found to be more common in non-invasive and papillary tumours. Similar findings were obtained by Tenti et $a l,{ }^{10}$ who found that p53 accumulation was more frequent in high grade transitional cell carcinoma than in low grade tumours, and that HPV infection was more common in low grade transitional cell carcinomas than those of a high grade. Kamel et $a l^{8}$ on the other hand, could find no inverse relation between HPV positivity and p53 accumulation in transitional cell carcinoma of the bladder.

Our study is the first to correlate HPV infection and p53 expression in inverted papilloma. We found that five of the six cases of inverted papilloma with demonstrable HPV type 18 had a p53 score of $2+$ or higher. On the other hand, two of the four HPV type 18 negative cases of inverted papilloma showed a p53 score of 0 . Although the number of cases of inverted papilloma are small, the result suggests a positive correlation between accumulation of p53 and HPV type 18 infection. This is notably different from the inverse correlation between the latter two that has been found by some investigators in cervical cancer ${ }^{21}$ and transitional cell carcinoma. ${ }^{70} \mathrm{HPV}$ type 18 may play a role in the pathogenesis of inverted papilloma by some mechanisms other than inactivation of the $\mathrm{p} 53$ protein.

This study was supported by a research grant (CRCG 335/046/ 0048) of The University of Hong Kong.

1 Lazarevic B, Garret R. Inverted papilloma and papillary transitional cell carcinoma of urinary bladder. Report of four cases of inverted papilloma, one showing papillary malignant transformation and review of the literature. Can cer 1978;42:1904-11.

2 Anderstrom C, Johansson S, Pattersson S. Inverted papilloma of the urinary tract. $f$ Urol 1982;127:1132-4.

3 Bryant P, Davies P, Wilson D. Detection of human papillomavirus DNA in cancer of the urinary bladder by in situ hybridisation. Br f Urol 1991;68:49-52.

4 Anwar $K$, Naiki $H$, Nakakuki $K$, Inuzuka $M$. High frequency of human papillomavirus infection in carcinoma of the urinary bladder. Cancer 1992;70:1967-73.

5 Shibutani YF, Schoenberg MP, Carpiniello VL, Malloy TR. Human papillomavirus associated with bladder cancer. Urology 1992;40:15-17.

6 Yu ST, Wu MM, Li LM. Prevalence of human papillomaviru ST, Wu MM, Li LM. Prevalence of human papillomaviruses 16 and 18 in transitional cell

7 Furihata M, Inoue K, Ohtsuki Y, Hashimoto H, Terao N Fujita Y. High-risk human papillomavirus infections and 
overexpression of $\mathrm{p} 53$ protein as prognostic indicators in transitional cell carcinoma of the urinary bladder. Cancer Res 1993;53:4823-7.

8 Kamel D, Paakko P, Pollanen R, Vahakangas K, Lehto VP, Soini Y. Human papillomavirus DNA and abnormal p53 expression in carcinoma of the urinary bladder. APMIS 1995;103:331-8.

9 Lopez Beltran A, Munoz E. Transitional cell carcinoma of the bladder: low incidence of human papillomavirus DNA detected by the polymerase chain reaction and in situ hybridization. Histopathology 1995;26:565-9.

10 Tenti P, Zappatore R, Romagnoli S, Civardi E, Giunta P, Scelsi $R$, et al. p 53 overexpression and human papillomavirus infection in transitional cell carcinoma of the urinary bladder: correlation with histological parameters. $f$ Pathol 1996;178;65-70

11 Chan KW, Lam KY, Srivastava G. Accumulation of p53 protein in inverted transitional cell papilloma of urinary bladder. 7 Clin Pathol: Mol Pathol 1996;49:M43-5.

12 Chan KW, Lam KY, Chan ACL, Lau P, Srivastava G. Prevalence of human papillomavirus types 16 and 18 in penile carcinoma: a study of 41 cases using PCR. $\mathcal{f}$ Clin Pathol 1994;47:823-6.

13 Saiki RK, Scharf S, Faloona F, Mullis KB, Horn GT, Erlich $\mathrm{HA}$, et al. Enzymatic amplification of beta-globin genomic sequences and restriction site analysis for diagnosis of sickle cell anemia. Science 1985;230:1350-4
14 Van Den Brule AJ, Walboomers JM, Du Maine $M$, Kenemans P, Meijer CJ. Difference in prevalence of human papillomavirus genotypes in cytomorphologically normal cervical smears is associated with a history of cervical intraepithelial neoplasia. Int $f$ Cancer 1991;48: 404-8. 15 Young LS, Bevan IS, Johnson MA, Blomfield PI, Bromidge epidemiological tool for investigating cervical human papillomavirus infection. BMf 1989;298:14-18.

16 Tidy JA, Farrell PJ, Vousden KH. Relation between infection with a subtype of HPV 16 and cervical neoplasia. Lancet 1989;i:1225-7.

17 Nyan HY, Stanley M, Liu SS, Ma HK. HPV and p53 in cervical cancer. Genitourin Med 1994;70:167-70.

18 Hollstein M, Sidransky D, Vogelstein B, Harris CC. p53 Hollstein M, Sidransky D, Vogelstein B, Harris CC.
mutations in human cancers. Science 1991;253:49-53.

19 Vogelstein B, Kinzler KW. p53 function and dysfunction. Cell 1992;70:523-6.

20 Scheffner M, Werness B, Huibregtse JM, Levine AJ, Howley $\mathrm{PM}$. The EG oncoprotein encoded by human papillomavirus type 16 and 18 promotes the degradation of $p 53$. Cell 1990;63:1129-36.

21 Lorincz AT, Temple GF, Kurman RJ, Jenson AB, Lancaster WD. Oncogene association of specific human papillomavirus types with cervical neoplasia. 7 Natl Cancer Inst 1987;79:671-7 